\title{
Evaluation of generalized extreme value and Gumbel distributions for estimating maximum daily rainfall
}

Avaliação das distribuições generalizada de valores extremos e Gumbel para a estimativa de chuvas máximas diárias Álvaro José Back ${ }^{1}$ (D), Fernanda Martins Bonfante ${ }^{2}$ (1)

\section{A B S T RAC T}

Extreme rain events can cause social and economic impacts in various sectors. Knowing the risk of occurrences of extreme events is fundamental for the establishment of mitigation measures and for risk management. The analysis of frequencies of historical series of observed rain through theoretical probability distributions is the most commonly used method. The generalized extreme value (GEV) and Gumbel probability distributions stand out among those applied to estimate the maximum daily rainfall. The indication of the best distribution depends on characteristics of the data series used to adjust parameters and criteria used for selection. This study compares GEV and Gumbel distributions and analyzes different criteria used to select the best distribution. We used 224 series of annual maximums of rainfall stations in Santa Catarina (Brazil), with sizes between 12 and 90 years and asymmetry coefficient ranging from -0.277 to 3.917. We used the Anderson-Darling, KolmogorovSmirnov (KS), and Filliben adhesion tests. For an indication of the best distribution, we used the standard error of estimate, Akaike's criterion, and the ranking with adhesion tests. KS test proved to be less rigorous and only rejected $0.25 \%$ of distributions tested, while Anderson-Darling and Filliben tests rejected $9.06 \%$ and $8.8 \%$ of distributions, respectively. GEV distribution proved to be the most indicated for most stations. High agreement (73.7\%) was only found in the indication of the best distribution between Filliben tests and the standard error of estimate.

Keywords: heavy rain; drainage; probability; territorial management.

\section{RE S U M 0}

Eventos extremos de chuvas podem causar impactos sociais e econômicos em vários setores. Conhecer o risco de ocorrência de eventos extemos é fundamental para o estabelecimento de medidas mitigadoras e para a gestão de riscos. A análise de frequências de séries históricas de chuva observadas por meio de distribuições teóricas de probabilidades é o método mais usado. As distribuições de probabilidade generalizada de valores extremos (GEV) e Gumbel destacam-se entre aquelas aplicadas à estimativa das chuvas máximas diárias. A indicação da melhor distribuição depende das características da série de dados usada no ajuste dos parâmetros e do critério utilizado para a seleção. Este trabalho teve como objetivo comparar as distribuições GEV e Gumbel e analisar os critérios usados para a seleção da melhor distribuição. Foram empregadas 224 séries de máximas anuais de estações pluviométricas de Santa Catarina, com tamanho entre 12 e 90 anos e coeficiente de assimetria variando de $-0,277$ a 3,917. Adotaram-se os testes de aderência de Anderson-Darling, Kolmogorov-Smirnov e Filliben. Para a indicação da melhor distribuição foram usados o erro padrão de estimativa, o critério de Akaike e o ranking com os testes de aderência. O teste Kolmogorov-Smirnov mostrou-se pouco rigoroso e somente rejeitou $0,25 \%$ das distribuições testadas, enquanto os testes de Anderson-Darling e de Filliben rejeitaram 9,06 e $8,8 \%$ das distribuições, respectivamente. A distribuição GEV mostrou-se a mais indicada na maioria das estações. Somente foi constatada alta concordância $(73,7 \%)$ na indicação da melhor distribuição entre os testes de Filliben e o erro padrão de estimativa.

Palavras-chave: chuvas intensas; drenagem; probabilidade; gestãoterritorial.

\footnotetext{
${ }^{1}$ Empresa de Pesquisa Agropecuária e Extensão Rural de Santa Catarina - Urussanga (SC), Brazil.

${ }^{2}$ Universidade do Extremo Sul Catarinense - Criciúma (SC), Brazil.

Correspondence address: Álvaro José Back - Rodovia SC 108, km 353, 1563 - Caixa Postal 49 - Estação - CEP: $88840-000$ - Urussanga (SC), Brazil. E-mail: ajb@epagri.sc.gov.br

Conflicts of interest: the authors declare that there are no conflicts of interest.
}

Funding: none.

Received on: 12/15/2020. Accepted on: 07/08/2021.

https://doi.org/10.5327/Z217694781015

This is an open access article distributed under the terms of the Creative Commons license. 


\section{Introduction}

The study of intense rainfall events is important for understanding the climatic reality of a place and for understanding and evaluating the consequences of the impacts they generate on different sectors of society. Selge et al. (2015) showed a high vulnerability of agricultural production and regional income due to the low adaptation to local climate conditions.

Most of the extreme rain events when they reach occupied areas, especially urban areas, negatively impact the socioeconomic system of these locations (Souza et al., 2014). Fernandes and Valverde (2017) highlighted that located and extreme climatic events impact, especially, the most socioeconomically susceptible populations, with higher levels of exposure and less resilience. From a social point of view, extreme events are considered as those episodes of rain in which material, human, and economic damage of great importance occurs and in which vulnerability and resilience play an important role in the analysis of the extreme event (Monteiro and Zanella, 2017).

Impacts related to extreme rainfall events cause a huge number of disorders and loses (Bork et al., 2017). Investigation of spatial and temporal distributions of heavy rains provides information for planning actions to prevent and minimize their impact.

Risk assessment is an important tool in natural disaster management. According to Mouri et al. (2013), risk assessment of natural disasters is defined as the assessment of both the probability of natural disaster occurrence and the degree of damage caused by natural disasters. Recently, many studies have focused on natural disaster risk analysis with probability distributions based on historical data, which are usually converted to frequencies. Regarding frequency analysis, particularly for extreme events, the objective is to define the events associated with a return period that provide information to carry out the design of hydraulic works, decreasing the uncertainty of the forecast (Molina-Aguilar et al., 2019).

Costa et al. (2018) commented that studies about the risks of extreme events enable the development of actions that minimize the effects of these events, thus strengthening the resilience of the affected communities, which generally have low technological development to overcome the damage triggered during disasters.

Water resource analysis using a statistical approach can increase our understanding of environmental contexts. These approaches have played important roles in disaster prevention, the environment, and climate change prediction. In some communities, extreme flood events no longer result in disasters because prevention strategies such as the construction of structured rivers and levees have been implemented (Mouri et al., 2013).

For insurance and indemnity matters, it is necessary to define the expected indemnity or the insured amount, which depends, of course, on the probability of an extreme event occurring. For this, it is neces- sary to adequately estimate the risks of extreme events, which requires the use of an appropriate probability distribution. Skees (2010) pointed out that ignoring this limitation can lead professionals to believe that they accurately accounted for exposure to catastrophic risk when this may not be true. A limited probability distribution adjustment in the sample data may underestimate or overestimate exposure to catastrophic risk.

Knowledge of extreme rainfall events is a requirement in drainage, waterproofing, and other engineering works, whether in urban or rural areas, because it allows the designer to consider the existing risks with the execution of the work and associate it with the best alternative, from an economic point of view, without disregarding technical issues of performance and safety (Souza et al., 2014). It is also important for proper soil management and prevention of water erosion (Santos et al., 2010). Maximum rainfall estimation with a given return period is essential for dimensioning hydraulic works such as drainage channels, manholes, storm drain, bridges, and dams (Almeida et al., 2015). The procedure adopted normally consists of using a theoretical distribution of probabilities, which must have its parameters previously adjusted based on the historical series of the annual maximums observed (De Paola et al., 2018).

There are several probability distributions, such as type I and type II extreme distributions, generalized extreme value (GEV), Pearson Type III, and Log-Pearson type III distributions, that can be used (Vivekanandan, 2015a). The type I extreme or Gumbel distribution and extensions have been applied to different areas of scientific knowledge such as hydrology, meteorology, climatology, insurance, finance, and geology, among many others (Nanvapisheh, 2021). The Gumbel distribution has been widely used to study maximum rainfall (Marques et al., 2014; Affonso et al., 2020).

The GEV distribution is widely employed for modeling the extreme precipitation in the environmental sciences and many other fields (Bella et al., 2020). GEV distribution has recently been indicated and is being widely used for precipitation frequency analysis for its capacity to include all three types of asymptotic distributions of extreme values (Gumbel, Fréchet, and Weibull).

In recent decades, many studies have been performed on the best fit of probability distributions for hydrological series. In addition, many countries use specific probability distributions to analyze maximum hydrologic events. Pearson type III distribution is recommended in China (Rizwan et al., 2018), while the United States adopted the Log-Pearson type III distribution (USWRC, 1981). Gumbel distribution is recommended in Canada (Das and Simonovic, 2011). Marra et al. (2017) highlighted that GEV is a three-parameter distribution of extreme values used worldwide to model rainfall extremes. Several European countries, such as Austria, Germany, Italy, and Spain, recommend the use of GEV distribution in studies of extreme events, such as rain and flood (Salinas et al., 2014). 
Several studies in the literature have investigated probability distribution models for extreme values of climatic variables, mainly Gumbel and GEV models, which are currently the best-fits models, with best performance (Das and Simonovic, 2011; Marques et al., 2014; Pérez-Sánchez and Senent-Aparicio, 2017; Alam et al., 2018; Yuan et al., 2018; González-Álvarez et al., 2019). Many studies indicate Gumbel distribution as the most suitable method (Almeida et al., 2015; Vivekanandan, 2015b; Cremoneze et al., 2017; Mistry and Suryanarayana, 2019), while others cite GEV distribution as the superior method (Das and Simonovic, 2011; Beskow et al., 2015; Namitha and Vinothkumar, 2019).

Besides the distribution to be used, the method to adjust parameters can interfere in the evaluation of distribution (Marques et al., 2014). Among methods for adjusting probability distribution parameters, we highlight the method of moments (MM), the method of maximum likelihood (ML), and the method of L-moments (LM) (Hosking, 1990). The method by Chow (1964) is still often used in Gumbel distribution, with this distribution being known as Gumbel-Chow (Back and Cadorin, 2020). The method of moments is considered simpler, but also less precise when compared with other procedures, such as the method of maximum likelihood (Vivekanandan and Shukla, 2015). The ML method is considered to maximize the plausibility of a given distribution to be represented by the parameters estimated. However, in some cases, small samples can produce estimators comparable or even inferior to other methods. The ML method also has the drawback of increased complexity in calculation routines to estimate parameters, as is the case of GEV distribution. Naghettini and Pinto (2007) highlighted that the method of moments can produce low-quality estimates compared with the ML method, especially when the distribution has three or more parameters. The authors highlighted that the LM method results in estimates comparable in quality with those of ML, being often more precise for samples with small number of observations. Hosking (1990) highlighted that the LM method is less affected by extremes in the data series.

Maximum precipitation series can be represented by more than one probability distribution, and it is important to select the best distribution to be used (Zhang et al., 2002; Mandal and Choudhury, 2015; Vivekanandan, 2015a; Feyissa and Tukura, 2019). We can select the best model based on tests comparing observed frequencies with theoretical frequencies. The adhesion tests most used in hydrology are the Kolmogorov-Smirnov (KS), Anderson-Darling (AD), chi-square, and Filliben correlation (Rf) tests.

The distribution to be adopted depends on the characteristics of the hydrological series, the method for parameter adjustment, and the criterion to be adopted in the selection of probability distribution. Numerous studies performed by different researchers show that the best distribution can be defined based on the analysis of adhesion distribution adjusted to the observed data. Therefore, no distribution should be indicated according to region or country (Vivekanandan and Shukla, 2015). Thus, identifying the most adequate probability distribution to the extreme events observed, as well as adjusting its parameters and evaluating the quality of this adjustment, is challenging in the study of extreme events.

Leite and Virgens Filho (2011) highlighted that an error can occur in data analysis because of disregarding the characteristics of the most appropriate probability distribution for the data under study. The authors stated that mistakes may result in the unnecessary use of a more complex and laborious model, as well as in the use of a simplified model, which would result in wrong conclusions, if the data do not adhere to this distribution. However, we observe that most studies show only the best fit obtained, while in many cases, two or more models fit properly, with very small differences, and often less laborious and sometimes equally efficient model options are not shown.

Feyissa and Tukura (2019) highlighted that the proper evaluation of flood frequency distribution is one of the main problems faced by hydrologists. This issue is very important as different distributions can produce significantly different estimates for the same return period (Coulson, 1991). Thus, this study evaluates Gumbel and GEV distributions with parameters estimated by different methods for the series of annual maximum daily rainfall in Santa Catarina.

\section{Materials and Methods}

Data

We analyzed daily rainfall data from rainfall stations located in the state of Santa Catarina, Brazil. We used rainfall stations belonging to the Hydrometeorological network of the National Water Agency (ANA, 2020) and the network of rainfall stations from the Santa Catarina Agricultural Research Company (EPAGRI, 2020). For each rainfall station, we determined the series of annual maximums between 1912 and 2019. We selected stations with series over 10 years, excluding years with failures in observations. We selected 224 rainfall stations with these criteria, with 201 stations from ANA and 23 stations from Epagri, whose spatial distribution can be observed in Figure 1.

\section{Probability distributions tested}

The GEV distribution incorporates three asymptotic forms of maximum extreme values in a single expression. The probability density function is given by Equation 1:

$f(x)=\frac{1}{\alpha}\left[1-k\left(\frac{x-\beta}{\alpha}\right)\right]^{\left(\frac{1}{k-1}\right)} \exp \left\{-\left[1-k\left(\frac{x-\beta}{\alpha}\right)\right]^{1 / k}\right\}$,

Where:

$\alpha=$ scale parameter.

$\beta=$ position parameter.

$k=$ form parameter. 
The value of signal $k$ determines the asymptotic form of maximum extreme values, that is, if $k<0$, GEV represents type II distribution, defined only for $X>(\beta+\alpha) / k$. If $k>0$, GEV represents type III distribution, defined only for $X<(\beta+\alpha) / k$. If $k=0$, GEV corresponds to Gumbel distribution with scale $(\alpha)$ and position $(\beta)$ parameters. Fréchet and Weibull extreme value distributions correspond to the particular cases in which $k>0$ and $k<0$, respectively.

Type I extreme distribution, also known as Gumbel distribution, has its probability density function given by Equation 2:

$f(x)=\alpha \exp \{-\alpha(X-\beta)-\exp (-\alpha(X-\beta))\}$,

Where:

$\alpha=$ the scale parameter (standard deviation of Gumbel distribution);

$\beta=$ the location parameter (Model) of Gumbel distribution.

\section{Parameter estimation}

We obtained parameter estimation of Gumbel and GEV distributions by the method of moments and maximum likelihood, as described by Kite (1977). For the method of L-moments, we used the procedures described by Hosking $(1994,2005)$.

\section{Adhesion tests}

We applied adhesion tests to test the following null hypothesis $\left(\mathrm{H}_{0}\right)$ : maximum daily rainfall data follow the distribution specified, against the alternative hypothesis $\mathrm{H}_{1}$ : maximum daily rainfall data do not follow the distribution specified. We used the adhesion tests of Kolmogorov-Smirnov, Anderson-Darling, and Filliben correlation (Rf), all at 5\% significance level $(\alpha=0.05)$.
For the KS test (Abreu et al., 2018), we calculated $D^{+}$and $D^{-}$differences given by Equations 3 and 4:

$D^{+}=\operatorname{Max}|\operatorname{Fn}(x)-F(x)|$,

$D^{-}=\operatorname{Max}|F(x)-\operatorname{Fn}(x)|$.

The test statistic is given by the highest $D^{+}$and $D^{-}$value, which was compared with the critical value $\left(D_{\text {crit }}\right)$ at $5 \%$ significance level. Whenever $D_{\max }$ value exceeds the $D_{\text {crit }}$ value, the distribution is rejected.

For the Anderson-Darling test (Abreu et al., 2018), we calculated the statistic by Equation 5:

$A^{2}=-N-\sum_{i=1}^{N} \frac{(2 i-1)\left\{\ln F_{X}\left(x_{(i)}\right)+\ln \left[1-F_{X}\left(x_{(N-i+1)}\right)\right]\right\}}{N}$.

For Gumbel distribution and GEV distribution, as recommended by Naghettini and Pinto (2007), we corrected the AD test statistic by Equation 6:

$\mathrm{ADc}=A^{2}(1+0.20 / \sqrt{ } N)$

We compared the calculated values of ADc statistics with the critical value at $5 \%$ significance level $\left(\mathrm{AD}_{\text {crit }}=0.757\right)$, recommended for Gumbel and GEV distributions (Naghettini and Pinto, 2007).

The Filliben adhesion test (1975) is based on the linear correlation coefficient Rf between observations ordered in increasing order and theoretical quantiles calculated by Equation 7:

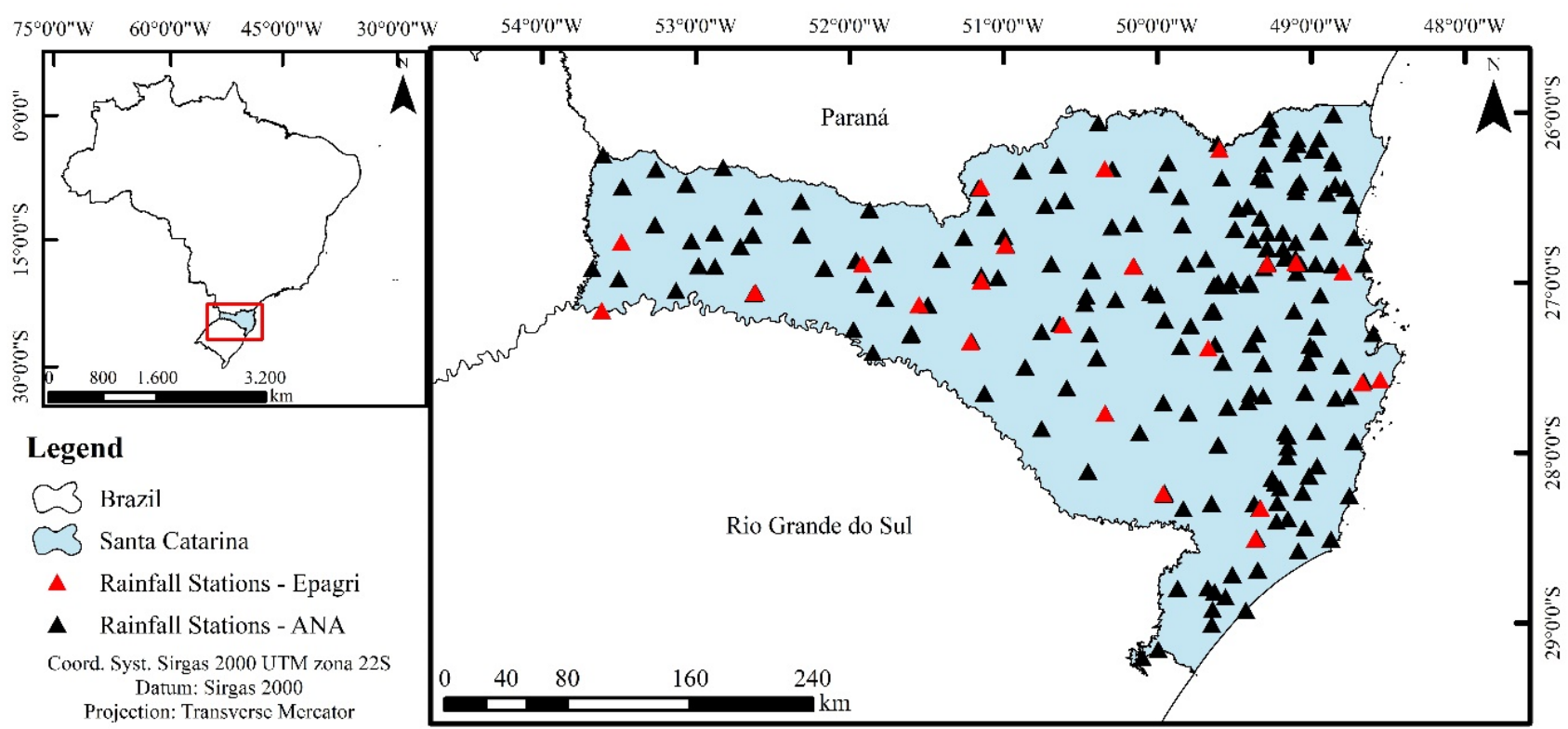

Figure 1 - Location of rainfall stations. 
$W_{i}=F_{x}^{-1}\left(1-q_{i}\right)$

Where:

$q_{\mathrm{i}}=$ the empirical probability corresponding to the order of classification given by Equation 8 :

$q_{i}=\frac{i-a}{N+1-2 a}$

Where:

$N=$ the series size;

$a=0.4$, according to the formula suggested by Cunnane (1973).

The Filliben test statistic is expressed by Equations 9, 10 and 11 (Abreu et al., 2018):

$\mathrm{Rf}=\frac{\sum_{i=1}^{N}\left(x_{i}-\bar{x}\right)\left(w_{i}-\bar{w}\right)}{\sqrt{\sum_{i=1}^{N}\left(x_{i}-\bar{x}\right)^{2} \sum_{i=1}^{N}\left(w_{i}-\bar{w}\right)^{2}}}$

where $\bar{x}=\frac{\sum_{i=1}^{N} x_{(i)}}{N}$

and $\bar{w}=\frac{\sum_{i=1}^{N} w_{i}}{N}$

The $\mathrm{Rf}$ value calculated is compared with the critical value $\left(R_{\text {crit }}\right)$ The Filliben test has the disadvantage that critical values depend on sample size, distribution to be tested, and the expression used to calculate empirical probability. In this study, we calculated critical values according to the equations shown by Heo et al. (2008).

\section{Distribution selection criteria}

In order to select the best distribution, we calculated values of standard error of estimate (Se) and used the Akaike's criterion. In addition, we considered a global ranking based on the total score obtained in three adhesion tests along with the other selection criteria. Each test was assigned a value from 1 to 7 , with the best distribution receiving the lowest value. Thus, the final score for each series tested ranges from 5 to 35 , and the best distribution was given by the lowest overall score of each series.

For the standard error of an estimate, we used the expression suggested by Equation 12 (Kite, 1977):

$\mathrm{Se}=\sqrt{\frac{\sum_{i 1}^{n}\left(X_{i}-X e_{i}\right)^{2}}{n-k}}$,

Where:

$\mathrm{Se}=$ the standard error for a given probability distribution;

$X_{\mathrm{i}}=$ the precipitation recorded of order $i$;

$X e_{\mathrm{i}}=$ the precipitation estimated by the theoretical probability distribution; $n=$ the number of elements in the series of annual maximums;

$k=$ the number of parameters estimated for probability distribution $(k$ $=2$ for Gumbel distribution and $k=3$ for GEV distribution).

Akaike's information criterion was developed to test whether a given model is suitable, defining its criterion as Equation 13:

AICc $=-2 \operatorname{LogLike}+2 k+\frac{2 k(K+1)}{N-k-1}$,

Where:

LogLike $=$ the Log-likelihood function of the probability distribution; $k=$ the number of model parameters.

For Gumbel distribution, we calculate the Log-likelihood function by Equation 14:

LogLike $=n \ln (\alpha)-\alpha \sum_{i=1}^{n}\left(X_{i}-\mu\right)-\sum_{i=1}^{n} \exp \left(-\alpha\left(X_{1}-\mu\right)\right.$,

While for GEV distribution, the Log-likelihood function is by Equation 15:

LogLike $=-n \ln (\alpha)-\left(\frac{1+k}{k}\right) \sum_{i=1}^{n} \ln \left[1+k\left(\frac{X_{i}-\beta}{\alpha}\right)\right]-\sum_{i=1}^{n}\left[1+k\left(\frac{X_{i}-\beta}{\alpha}\right)\right]^{-1 / k}$.

According to this criterion, the best model considered for problem construction is the one with the lowest Akaike's information criterion (AICc) value. This criterion penalizes the addition of parameters, that is, the selection of an extremely complex model with many parameters (Ramos and Moala, 2014).

\section{Results and Discussion}

Table 1 contains the summary of descriptive statistics of the series of annual maximums. In the 224 series studied, series size ranged from 12 to 90 years, with $25 \%$ of the series containing up to 29 years and $25 \%$ of the series containing more than 50 years of data. Series means ranged from 55.7 to $134.8 \mathrm{~mm}$, although $50 \%$ of the series averaged in the $79.8-96.6 \mathrm{~mm}$ range. The variation coefficient ranged from 27.5 to $47.2 \%$, with $50 \%$ of series between 27.2 and $31.9 \%$. Regarding extremes, we found that the highest values in each series range from 95.5 to $367 \mathrm{~mm}$, although $50 \%$ of the series had maximum values within the 138.3-196.2 mm range. The asymmetry coefficient ranged from -0.277 to 3.917 , with only eight stations (3.6\%) having negative asymmetry and $25 \%$ of the series with asymmetry below 0.50 . In addition, $25 \%$ of series showed asymmetry above 1.22 and only $6.7 \%$ showed asymmetry above 2.0 . Alam et al. (2018) stated that series with asymmetry coefficient above 1.0 can be considered highly asymmetric, while asymmetry from 0.5 to 1 is considered moderately asymmetric. Series with asymmetry from -0.5 to 0.5 can be considered approximately symmetric. 
Table 2 shows rejection frequencies for the adhesion tests of distributions fitted to the series of annual maximums. The KS test only rejected four distributions (0.25\%), one for the Gumbel-MM distribution, two for the Gumbel-Chow distribution, and one for GEV-LM. These series rejected by the KS test contained asymmetry coefficient above 2.8 with extreme values above $300 \mathrm{~mm}$, which can be an outlier in the series. As the KS test is based only on the greatest difference between observed and estimated frequencies, an outlier can imply the rejection of the adhesion hypothesis. We obtained 142 rejections for the 1568 tested (224 series $\times 7$ candidate distributions) with the Anderson-Darling test, equivalent to $9.06 \%$ rejection. The Rf test rejected the Gumbel distribution for 19 series analyzed (8.5\%). The Gumbel distribution adjustment for the eight series with asymmetry coefficient above 2 was rejected by the Rf test. Among GEV distributions, the Rf test rejected 62 series, the majority being of GEV-MV distribution. Considering the total series, the Rf test rejected $8.8 \%$ of series.

Thus, we observed that the KS test is little rigorous in rejecting adhesion hypotheses to the series of annual maximums. Abreu et al. (2018) obtained similar results. One of the criticisms of KS test is that its application assumes that the distribution to be tested is previously known. However, in applications, we usually adjusted distribution parameters based on the series to be tested. Even with these limitations, the KS test is widely used often as the only adhesion test (Al-Suhili and Khanbilvardi, 2014; Pereira et al., 2017; Silva Neto et al., 2017; Ottero et al., 2018) and also commonly used as criterion for selecting the best distribution (Caldeira et al., 2015; Back and Cadorin, 2020). AD and Rf tests proved to be more rigorous and should be favored. Gumbel distribution was the most rejected as some series show negative asymmetry, and other series show asymmetries above 2.0. Gumbel distribution has a theoretical asymmetry coefficient of 1.1396 . Thus, it is normal that series with asymmetry far from this value are considered inadequate. On the contrary, GEV distribution has the $k$ parameter that allows better adjustment to the format of data distribution.

Beskow et al. (2015) obtained similar results, who analyzed data from 342 rainfall stations in the state of Rio Grande do Sul and found that the KS test did not reject any GEV distribution and rejected only $0.29 \%$ of Gumbel distributions. For the AD test, rejections were of $2.92 \%$ and $13.45 \%$ for GEV and Gumbel distribution, respectively. These rejections were of $2.05 \%$ and $8.19 \%$ by the Rf test, respectively. The authors concluded that the AD adhesion test was the most appropriate to evaluate the adequacy of probability models to the historical series analyzed, as being more restrictive than $\mathrm{Rf}$ and KS tests.

Marques et al. (2014) analyzed series of maximum rainfall in the state of Minas Gerais and analyzed the performance of GEV, Gumbel, and Gama probability distributions with two parameters, concluding that the Gumbel probability distribution performed better, adjusting to $87.5 \%$ of cases. Among probability distributions evaluated, GEV adjusted by ML method showed adhesion for all rainfall stations, being indicated for use. Mello and Silva (2005) also compared the adjustment of parameters by MM and ML using the chi-square adhesion test and concluded that the ML method performed better. Abreu et al. (2018) observed that adhesion tests can indicate different results regarding adequacy of probability distributions and concluded that the KS test was the least rigorous, admitting adhesion in all situations tested.

Table 3 shows frequencies in which different distributions were identified as the best according to different criteria. Using the criterion of lowest value of the KS statistic, Gumbel distribution was identified as the best in 83 series analyzed (11 MM, $23 \mathrm{ML}, 13 \mathrm{LM}$, and 36 using the Gumbel-Chow method), and 141 series indicate GEV distribution as the best (37 MM, $43 \mathrm{ML}$, and $61 \mathrm{LM}$ ). By the Anderson-Darling

Table 2 - Frequency of rejection of the adhesion hypothesis.

\begin{tabular}{|l|c|c|c|}
\hline \multirow{2}{*}{ Distribution tested } & \multicolumn{3}{|c|}{ Adhesion test } \\
\cline { 2 - 4 } & $\begin{array}{c}\text { Kolmogorov- } \\
\text { Smirnov }\end{array}$ & $\begin{array}{c}\text { Anderson- } \\
\text { Darling }\end{array}$ & Filliben \\
\hline Gumbel-MM & 1 & 42 & 19 \\
\hline Gumbel-MV & 0 & 25 & 19 \\
\hline Gumbel-LM & 0 & 27 & 19 \\
\hline Gumbel-Chow & 2 & 13 & 19 \\
\hline GEV-MM & 0 & 21 & 7 \\
\hline GEV-MV & 0 & 7 & 47 \\
\hline GEV-LM & 1 & 7 & 8 \\
\hline Total & 4 & 142 & 138 \\
\hline
\end{tabular}

Table 1 - Summary of descriptive statistics of the series of annual maximums.

\begin{tabular}{|c|c|c|c|c|c|c|}
\hline \multirow{2}{*}{ Statistics } & \multirow{2}{*}{ Nr. of data } & \multirow{2}{*}{ Mean (mm) } & \multicolumn{2}{|c|}{ Coefficient of } & \multirow{2}{*}{ Highest (mm) } & \multirow{2}{*}{ Lowest (mm) } \\
\hline & & & Variation (\%) & Asymmetry & & \\
\hline Maximum & 90 & 134.8 & 47.2 & 3.917 & 367.0 & 85.2 \\
\hline Minimum & 12 & 55.7 & 27.5 & -0.277 & 95.5 & 15.3 \\
\hline Mean & 40.3 & 89.4 & 30.8 & 0.910 & 169.7 & 47.9 \\
\hline 1st Quartile & 29 & 79.8 & 27.2 & 0.504 & 138.3 & 41.0 \\
\hline 2nd Quartile & 38 & 88.0 & 29.1 & 0.789 & 160.8 & 47.3 \\
\hline 3rd Quartile & 50 & 96.6 & 31.9 & 1.219 & 196.2 & 54.2 \\
\hline Quartile Range & 21 & 16.8 & 54.5 & 0.715 & 57.9 & 13.2 \\
\hline
\end{tabular}


test, Gumbel distribution was selected in 75 series, 57 of which use the Gumbel-Chow method. GEV distribution was selected in 149 series, 88 of which use the LM method. Similar results were obtained by Lima et al. (2021), who reported that the GEV distribution had the best performance in Anderson-Darling test and it was suitable to represent series with positive skewness with high values. Also Back and Cadorin (2020), comparing the Gumbel and GEV distribution in 11 pluviometric stations in the state of Acre, concluded that the GEV distribution with parameters estimated by the LM method was considered the best in $73 \%$ of the stations. Rf criterion indicated Gumbel distribution as the best in 24 series, indicating GEV distribution for the remaining 200 series. The Rf criterion does not distinguish between adjustment methods of Gumbel distribution. In the Akaike's criterion, GumbelML distribution, with 172 series, and GEV-ML distribution, with 40 series, stood out. In Akaike's criterion, adjustment methods using maximum likelihood stand out for considering the Log-likelihood function in the calculation, which is minimized in the parameter adjustment process. Moretti and Mendes (2003) showed that small samples cause quality loss and less precision in parameter estimates using the method of maximum likelihood. Molina-Aguilar et al. (2019) highlighted that multiple methods for estimating the parameters of the Gumbel distribution function are reported in the literature, with the moments and ML methods being the best known and most used of them all.

In the criterion standard error of estimation, GEV distribution also prevailed with 192 series, of which GEV-MM is the most frequent. Adopting the ranking, GEV distribution is indicated in 164 series and Gumbel distribution is indicated in 60 series. González-Álvarez et al. (2019) reported similar results when investigating whether the Gumbel was most suitable, based on 318 rain gauges from the Caribbean region. They concluded that GEV was most suitable in $47.2 \%$ of the rain gauges, while Gumbel, in spite of being widely used in Colombia, was only suitable in $34.3 \%$ of the cases. Coronado-Hernández et al. (2020), with records from 362 stations distributed throughout Colombia, concluded that GEV distribution presents the best fit with an overall value of $52 \%$.

Table 3 - Indication of the best probability distribution according to the selection criteria.

\begin{tabular}{|l|c|c|c|c|c|c|}
\hline \multirow{2}{*}{$\begin{array}{l}\text { Probability } \\
\text { distribution }\end{array}$} & \multicolumn{7}{|c|}{ Selection criteria } \\
\cline { 2 - 8 } & KS & AD & Rf & AK & Se & Ranking \\
\hline Gumbel-MM & 11 & 1 & $24^{*}$ & 0 & 2 & 10 \\
\hline Gumbel-ML & 23 & 8 & $24^{\star}$ & 172 & 1 & 20 \\
\hline Gumbel-LM & 13 & 9 & $24^{\star}$ & 6 & 25 & 23 \\
\hline Gumbel-Chow & 36 & 57 & $24^{\star}$ & 6 & 4 & 7 \\
\hline GEV-MM & 37 & 17 & 73 & 0 & 93 & 49 \\
\hline GEV-ML & 43 & 44 & 53 & 40 & 22 & 53 \\
\hline GEV-LM & 61 & 88 & 74 & 0 & 77 & 62 \\
\hline
\end{tabular}

${ }^{*}$ Non-differentiated between Gumbel distributions.
We observed that distribution selection varies according to the criterion used, and the lack of agreement between most of these criteria is evident. Table 4 shows the agreement matrix in the selection of distribution between criteria. The KS criterion showed $32.6 \%$ agreement with the $\mathrm{AD}$ criterion, that is, in $32.6 \%$ of series, the best distribution was selected equally by $\mathrm{KS}$ and $\mathrm{AD}$ criteria. Agreement of KS criteria with $\mathrm{Rf}$ and Akaike's criteria and standard error of estimate were $16.5,13.8$, and $13.8 \%$, respectively. Regarding ranking criteria, agreement was $29.5 \%$. We note that, even for completely random events, we expected $14 \%$ agreement. Thus, we state that there is no agreement between KS, Rf, and Se criteria. For the AD criterion, agreement with Rf, Akaike's, and Se criteria was 19.2, 12.1, and 17.9\%, respectively, and agreement with the ranking was $36.2 \%$. The Rf criterion had $73.7 \%$ agreement with the standard error of estimate. These were the indexes with the greatest agreement observed, reflecting increased compliance with the ranking. Abreu et al. (2018), who evaluated criteria for choosing probability distributions, also concluded that the Filliben test was the one with greatest convergence when considering the three best performances. Akaike's criterion showed the least agreement with other criteria, being only $5.4 \%$ with standard error and $17.4 \%$ with the sum of the ranking. These results show that different criteria used in the selection of distribution may indicate different probability distributions to be used. Akaike's criterion did not show significant agreement with any other criteria for privileging distributions estimated by the method of maximum likelihood. The greatest agreement, observed between $\mathrm{Rf}$ and Se methods (73.4\%), can be explained as both consider differences between all precipitation values observed and estimated and distribution, while the KS criterion considers only the greatest difference.

As different criteria indicate different distributions, several authors (Mandal and Choudhury, 2015; Alam et al., 2018) have been making a ranking considering all indexes. In this case, agreement for KS criterion is 29.5 and $36.25 \%$ for $\mathrm{AD}, 47.8 \%$ for Rf, and $48.2 \%$ for Se. Akaike's criterion has only $17.4 \%$ agreement, practically not differentiating from the completely random value. This fact reinforces that although the Akaike criterion is an index used to select models in general, its application in the selection of probability distribution is not in line with the other criteria and contributes less to the general score.

Table 4 - Agreement matrix between adhesion criteria.

\begin{tabular}{|l|c|c|c|c|c|c|}
\hline \multirow{2}{*}{ Criterion } & \multicolumn{6}{|c|}{ Classification criteria } \\
\cline { 2 - 7 } & KS & AD & Rf & AK & Se & Ranking \\
\hline KS & 1.000 & 0.326 & 0.165 & 0.138 & 0.138 & 0.295 \\
\hline AD & 0.326 & 1.000 & 0.192 & 0.121 & 0.179 & 0.362 \\
\hline Rf & 0.165 & 0.192 & 1.000 & 0.129 & 0.737 & 0.478 \\
\hline AK & 0.138 & 0.121 & 0.129 & 1.000 & 0.054 & 0.174 \\
\hline Se & 0.138 & 0.179 & 0.737 & 0.054 & 1.000 & 0.482 \\
\hline Ranking & 0.295 & 0.362 & 0.478 & 0.174 & 0.482 & 1.000 \\
\hline
\end{tabular}


Some authors, besides using quantitative criteria, also adopted qualitative criteria, mainly with the evaluation of Q-Q plot or distribution curve graphs with confidence interval (Aiyelokun et al., 2017). Qualitative evaluation is feasible when evaluating some distributions for a data series. However, for studies evaluating hundreds of series and various distributions, graphical analysis is unfeasible.

Figure 2 shows percentage differences between distribution estimated by Gumbel and GEV best ranked with the distribution selected by the ranking criteria. We observe that quartiles of differences are within the range of -7.8 and $+1.8 \%$ with Gumbel distribution for a return period of up to 50 years. This means that differences between rainfall estimated by these distributions are lower than $10 \%$ for more than $50 \%$ of the series studied. Differences are even lower for GEV distribution. This finding explains reduced agreement in the distribution selection criteria, as in most cases differences are insignificant, and more than one of distributions tested can be used to estimate maximum rainfall. Thus, distribution classified in the second or third place in the ranking can estimate rainfall with nonsignificant differences from the distribution in the first place.

On the contrary, we observe that some series show differences of more than $20 \%$ with Gumbel distribution estimates for a return period of above 20 years, reaching $84 \%$ with a return period of 1,000 years. For GEV distribution, differences above $20 \%$ were only observed with a return period of more than 100 years. These results are in consonance with Coelho et al. (2017), who reported differences greater than $18 \%$ in the maximum rainfall calculated with the GEV and Gumbel distributions with parameters estimated by the methods of moments and L-moments method. Back (2018), who analyzed maximum flow estimates with different probability distributions, observed that for the 10 -year return period, differences were

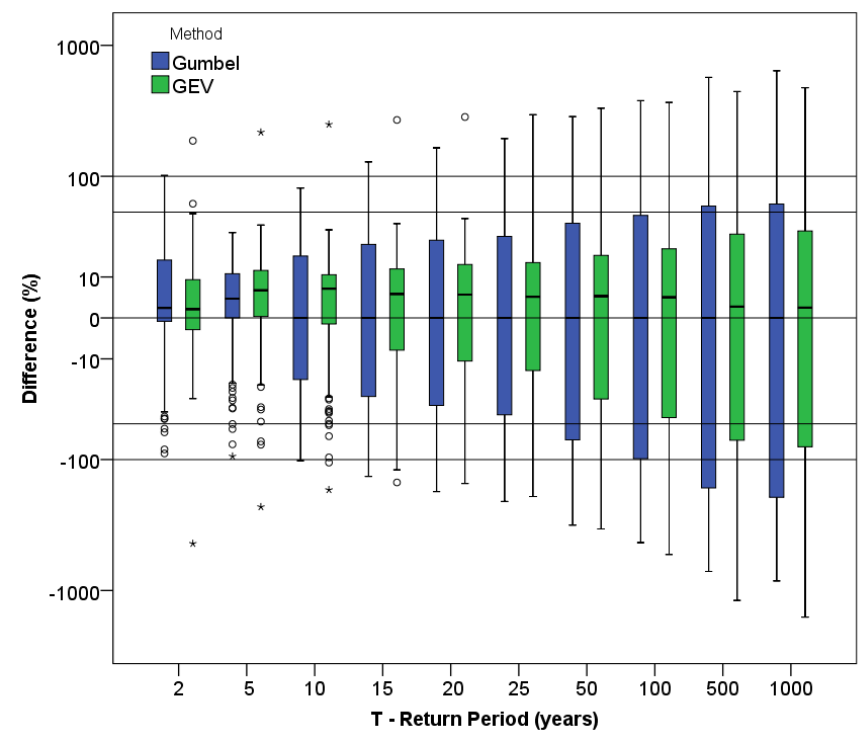

Figure 2 - Differences (\%) between maximum rainfall estimated with the best-ranked Gumbel and GEV distributions and maximum rainfall estimated with the distribution selected using ranking criteria. below $10 \%$, while differences could be above $20 \%$ for the 100 -year return period. Therefore, we highlight the importance of careful analysis of the probability distribution to be used in the estimation of extreme events with a return period of 100 years or more. In dam projects, the recommendation is to use a return period of up to 10,000 years. In these cases, we can obtain very different estimates for maximum rainfall according to the distribution selected, even if we perform adhesion test.

Esteves (2013) showed that extreme rainfall estimates for long return periods can differ by more than $40 \%$ depending on the distribution model used and question whether the level of protection they offer are appropriate in locations where data demonstrate clearly that alternative probability distributions may have a better fit to the local rainfall data. Adequate selection of the probability distribution is one of the more important issues in flood frequency analysis.

Fischer et al. (2012) claimed that extreme weather events regularly cause damages to ecosystems and affect the socioeconomic sphere. The population that is living in areas vulnerable to weather extremes such as floods, rain, storms, and droughts is increasing. Statistically, weather index insurance covers the extreme tail of the probability distribution of weather events for a specified region. The determination of the index depends on the probabilities associated with the given risk. An accurate estimation of return levels at given return periods is relevant for the determination of indices for weather index-based crop insurance and other adaptation measure.

\section{Conclusions}

The use of 224 series of maximum annual rainfall data ranging from 12 to 90 years, with asymmetry coefficient ranging from -0.277 to 3.917 , allows important conclusions on parameter adjustment and selection of probability distributions to estimate maximum extreme rainfall.

The Kolmogorov-Smirnov test is little rigorous as adhesion test criterion to adjust probability distributions to maximum annual rainfall data. In addition, its use to indicate the best probability distribution does not demonstrate confidence. Anderson-Darling and Filliben tests were more rigorous, rejecting 9.06 and $8.5 \%$ of the distributions tested, respectively. Filliben test also showed that it can be used as a criterion to select the best distribution, showing $73.7 \%$ agreement with the criterion with the lowest standard error of estimate.

Akaike's criterion showed less agreement with the other criteria tested, and for considering the likelihood function in calculation, only indicated Gumbel and GEV distributions with parameters estimated by the method of maximum likelihood. The ranking consisting of several criteria can be an alternative to select the best probability distribution, although not superior to the use of standard error of estimate or Filliben test.

The GEV distribution was selected as the best distribution for most of the series used in all selection criteria. However, all distributions adjusted with the different parameter estimation methods showed rejections by Anderson-Darling and Filliben tests. This finding reinforc- 
es the need to look for the best distribution to fit the data observed, especially when the series is asymmetric or has the presence of extreme values. A single distribution cannot be indicated for all cases.

The selection of the probability distribution can affect the estimates of extreme events and thus impact the determination of maximum flows with consequences in the dimensioning of hydraulic works and definition of risk areas, and influence the cost of insurance against extreme events.
As the return periods gets longer, the differences between the rainfall estimates obtained with the different probability distributions are more accentuated. Therefore, we recommend careful analysis of adjustment to select the most adequate probability distribution to estimate extreme events with return periods of 100 years or more. Detailed analysis of the fit of probability distributions to the observed data series is a better alternative than assuming a priori that a given probability distribution is adequate.

\section{Contribution of authors:}

Back, Á.J.: Conceptualization, Methodology, Investigation, Writing — original draft; Bonfante, F.M.: Organization, Formal analysis, Writing — review and editing.

\section{References}

Abreu, M.C.; Cecílio, R.A.; Pruski, F.F.; Santos, G.R.; Almeida, L.T.; Zanettim, S.S., 2018. Critérios para escolha de distribuições de probabilidade em estudos de Eventos extemos de precipitação. Revista Brasileira de Meteorologia, v. 33, (4), 601-613. http://dx.doi.org/10.1590/0102-7786334004.

Affonso, V.; Faria, G.A.; Lopes, B.G.; Tsutsumoto, N.Y.; Fonseca, A.D.; Felizardo, L.M., 2020. Análise dos dados de precipitação máxima no noroeste paulista pela teoria dos valores extremos. Research, Society and Development, v. 9, (10), e9709109396. https://doi.org/10.33448/rsd-v9i10.9396.

Agência Nacional das Águas (ANA). Sistema de Informações Hidrológicas (Accessed October 8, 2020) at: http://hidroweb.ana.gov.br/.

Aiyelokun, O.; Ojelabi, A., Malomo, S.; Agbede, O., 2017. Efficient flood forecasting for the operation of hydraulic structures in a typical river basin. International Journal of Scientific \& Engineering Research, v. 8, (11), 463-481.

Alam, M.A.; Emura, K.; Farnham, C.; Yuan, J., 2018. Best-Fit Probability Distributions and Return Periods for Maximum Monthly Rainfall in Bangladesh. Climate, v. 6, (1), 9. https://doi.org/10.3390/cli6010009.

Almeida, K.N., Reis, J.A.T.; Mendonça, A.S.F., 2015. Avaliação do desempenho dos métodos expeditos de determinação de equações de chuvas intensas. Brazilian Journal of Environmental Sciences, (35), 63-77 (Accessed December, 2020) at: http://www.rbciamb.com.br/index.php/Publicacoes_RBCIAMB/article/view/207

Al-Suhili, R.H.; Khanbilvardi, R., 2014. Frequency Analysis of the Monthly Rainfall Data at Sulaimania Region, Iraq. American Journal of Engineering Research, v. 3, (5), 212-222.

Back, Á.J., 2018. Análise de frequência de vazões máximas para projetos de drenagem. Revista Técnico-Científica de Engenharia Civil, v. 1, (2), 1-14. http://dx.doi.org/10.18616/civiltec.vli2.5065.

Back, Á.J.; Cadorin, S.B., 2020. Extreme rainfall and intensity-duration-frequency equations for the state of Acre, Brazil. Brazilian Journal of Environmental Sciences, v. 55, (2), 159-170. https://doi.org/10.5327/Z2176-947820200597.

Bella, N.; Dridi, H.; Kalla, M., 2020. Statistical modeling of annual maximum precipitation in Oued El Gourzi Watershed, Algeria. Applied Water Science, v. 10, 94. https://doi.org/10.1007/s13201-020-1175-6.

Beskow, S.; Caldeira, T.L.; Mello, C.R.; Faria L.C.; Guedes, H.A.S., 2015. Multiparameter probability distributions for heavy rainfall modeling in extreme southern Brazil. Journal of Hydrology: Regional Studies, 4, (part B), 123-133. https://doi.org/10.1016/j.ejrh.2015.06.007.
Bork, C.K.; Castro, A.S.; Leandro, D.; Corrêa, L.B.; Siqueira, T.M., 2017. Índices de precipitação extrema para os períodos atual (1961-1990) e futuro (2011-2100) na bacia do rio Taquari-antas, RS. Brazilian Journal of Environmental Sciences, (46), 29-45. https://doi.org/10.5327/Z2176947820170233

Caldeira, T.L.; Beskow, S.; Mello, C.R.; Faria, L.C.; Souza, M.R.; Guedes, H.A.S., 2015. Modelagem probabilística de eventos de precipitação extrema no estado do Rio Grande do Sul. Revista Brasileira de Engenharia Agrícola e ambiental, v. 19, (3), 197-203. http://dx.doi.org/10.1590/1807-1929/agriambi. v19n3p197-203.

Chow, V.T., 1964. Handbook of applied hydrology. McGraw-Hill Co., New York, $42 \mathrm{pp}$.

Coelho Filho, J.A.P.; Melo, D.C.R.; Araújo, M.L.M., 2017. Estudo de chuvas intensas para a cidade de Goiânia/GO por meio da modelação de eventos máximos anuais pela aplicação das distribuições de Gumbel e generalizada de valores extremos. Ambiência, v. 13, (1), p. 75-88. http://dx.doi.org/10.5935/ ambiencia.2017.01.05.

Coronado-Hernández, O.C.; Merlano-Sabalza, E.; Díaz-Vergara, Z.; CoronadoHernández, J.R., 2020. Selection of Hydrological Probability Distributions for Extreme Rainfall Events in the Regions of Colombia. Water, v. 12, (5), 1397. http://dx.doi.org/10.3390/w12051397.

Costa, J.N.; Silva Júnior, J.B.; Araújo, S.M.S., 2018. Riscos e desastres relacionados a eventos extremos (climáticos e meteorológicos) no estado da Paraíba. Revista de Geociências do Nordeste, v. 4, 110-125.

Coulson, C.H., 1991. Manual of operational hydrology in B.C., 2ndedn B.C. Water Management Division, Hydrology Section, Ministry of Environment, Landsand Parks, BC, Canada.

Cremoneze, I.Z.; Peralta, D.; Mazucheli, J.; Emanuelli, I.P., 2017. Análise de frequências das precipitações máximas mensais observadas nos estados do Paraná e Rio Grande do Sul. Enciclopédia Biosfera, v. 14, (25), 48-57.

Cunnane, C., 1973. A particular comparison of annual maxima and partial duration series methods of flood frequency prediction. Journal of Hydrology, v. 18, (3-4), 257-271. https://doi.org/10.1016/0022-1694(73)90051-6.

Das, N.M.S.; Simonovic, S.P., 2011. The comparison of GEV, Log-Pearson type 3 and Gumbel distributions in the Upper Thames River Watershed under global climate models. Water Resources Research Report, London, 54 pp. 
De Paola, F.; Giugni, M.; Pugliese, F.; Annis, A; Nardi, F., 2018. GEV parameter estimation and stationary vs. non-stationary analysis of extreme rainfall in African test cities. Hydrology, v. 5, (2), 28. https://doi.org/10.3390/ hydrology5020028.

Empresa de Pesquisa Agropecuária e Extensão Rural de Santa Catarina (EPAGRI). 2020. Banco de dados de variáveis ambientais de Santa Catarina. Epagri, Florianópolis, 20 p. (Epagri, Documentos, 310).

Esteves, L., 2013. Consequences to flood management of using different probability distributions to estimate extreme rainfall. Journal of Environmental Management, v. 115, 98-105. https://doi.org/10.1016/j. jenvman.2012.11.013.

Fernandes, RA.; Valverde, M.C., 2017. Análise da resiliência aos extremos climáticos de chuva: estudo preliminar na região de Mauá no ABC Paulista São Paulo. Brazilian Journal of Environmental Sciences, (44), 1-17. https://doi. org/10.5327/z2176-947820170183.

Feyissa, T.A.; Tukura, N.G., 2019. Evaluation of the best-fit probability of distribution and return periods of river discharge peaks. Case study: Awetu River, Jimma, Ethiopia. Journal of Sedimentary Environments, v. 4, (4), 360368. https://doi.org/10.12957/jse.2019.46128.

Filliben, J.J., 1975. The probability plot correlation coefficient test for normality. Technometrics, v. 17, (1), 11-117. https://doi.org/10.2307/1268008.

Fischer, T.; Su, B.; Luo, Y.; Scholten, T., 2012. Probability Distribution of Precipitation Extremes for Weather Index-Based Insurance in the Zhujiang River Basin, South China. Journal of Hydrometeorology, v. 13, (3), 1023-1037. https://doi.org/10.1175/JHM-D-11-041.1.

González-Álvarez, Á.; Viloria-Marimón, O.M.; Coronado-Hernández, Ó.E.; Vélez-Pereira, A.M.; Tesfagiorgis, K.; Coronado-Hernández, J.R., 2019. Isohyetal maps of daily maximum rainfall for different return periods for the Colombian Caribbean Region. Water, v. 11, (2), 358. https://doi.org/10.3390/ w11020358.

Heo, J.H.; Kho, Y.W.; Shin, H.; Kim, S.; Kim, T., 2008. Regression equations of probability plot correlation coefficient test statistics from several probability distributions. Journal of Hydrology, v. 355, (1-4), 1-15. https://doi. org/10.1016/j.jhydrol.2008.01.027.

Hosking, J.R.M., 1990. L-moments: analysis and estimation of distributions using linear combinations of order statistics. Journal of the Royal Statistical Society. Series B. Statistical Methodological, v. 52, (1), 105-124 (Accessed December, 2020) at: https://www.jstor.org/stable/2345653.

Hosking, J.R.M., 1994. The four-parameter Kappa distribution. IBM Journal of Research and Development, v. 38, (3), 251-258. https://doi.org/10.1147/ rd.383.0251.

Hosking, J.R.M., 2005. FORTRAN routines for use with the method of L-moments. Version 3.04, Rep. No. RC 20525 (90933). IBM Research Division, T.J. Watson Research Center, Yorktown Heights, NY.

Kite, G.W., 1977. Frequency and risk analyses in hydrology. Water Resources Publications, Fort Collins, Colorado, 224 pp.

Leite, M.L.; Virgens Filho, J.S., 2011. Ajuste de modelos de distribuição de probabilidade a séries horárias de velocidade do vento para o município de Ponta Grossa, Estado do Paraná. Acta Scientiarum. Technology, v. 33, (4), 447455. https://doi.org/10.4025/actascitechnol.v33i4.7072.

Lima, A.O.; Lyra, G.B.; Abreu, M.C.; Oliveira-Júnior, J.F.; Zeri, M.; CunhaZeri, G., 2021. Extreme rainfall events over Rio de Janeiro State, Brazil: Characterization using probability distribution functions and clustering analysis. Atmospheric Research, v. 247, 1052212. https://doi.org/10.1016/j. atmosres.2020.105221.
Mandal, S.; Choudhury, B.U., 2015. Estimation and prediction of maximum daily rainfall at Sagar Island using best fit probability models. Theoretical Appied Climatolology, v. 121, (1-2), 87-97. https://doi.org/10.1007/s00704014-1212-1.

Marques, R.F.P.V.; Mello, C.R.; Silva, A.M.; Franco, C.S.; Oliveira, A.S., 2014. Desempenho de distribuições de probabilidades aplicadas a eventos extremos de precipitação diária. Ciência Agrotecnologia, v. 38, (4), 335-342. https://doi. org/10.1590/S1413-70542014000400003.

Marra, F.; Morin, E.; Peleg, N.; Mei, Y.; Anagnostou, E.N., 2017. Intensityduration-frequency curves from remote sensing rainfall estimates: comparing satellite and weather radar over the eastern Mediterranean. Hydrology and Earth System Sciences, v. 21, (5), 2389-2404. https://doi.org/10.5194/hess-212389-2017.

Mello, C.R.; Silva, A.M., 2005. Métodos estimadores dos parâmetros da distribuição de Gumbel e sua influência em estudos hidrológicos de projeto. Irriga, v. 10, (4), 318-334. https://doi.org/10.15809/irriga.2005v10n4p334-350.

Mistry, P.B.; Suryanarayana, M.V., 2019. Estimation of annual one day maximum rainfall using probability distributions for Waghodia Taluka, Vadodara. Global Research and Development Journal for Engineering, 296300 (Accessed November, 2020) at: https://www.grdjournals.com/uploads/ conference/GRDCF/012/059/GRDCF012059.pdf

Molina-Aguilar, J.P.; Gutierrez-Lopez, A.; Raynal-Villaseñor, J.A.; GarciaValenzuela, L.G., 2019. Optimization of Parameters in the Generalized Extreme-Value Distribution Type 1 for Three Populations Using Harmonic Search. Atmosphere, v. 10, (5), 257. http://dx.doi.org/10.3390/atmos10050257.

Monteiro, J.B.; Zanella, M.E., 2017. A metodologia dos máximos de precipitação aplicada ao estudo de eventos extremos diários nos municípios de Crato, Fortaleza e Sobral-CE. GeoTextos, v. 13, (2), 135-159. http://dx.doi. org/10,977/194-5537geo.v13i2.24011.

Moretti, A.R.; Mendes, B.V.M., 2003. Sobre a precisão das estimativas de máxima verossimilhança nas distribuições bivariadas de valores extremos. Pesquisa Operacional, v. 23, (2), 301-324. https://doi.org/10.1590/S010174382003000200004.

Mouri, G.; Minoshima, D.; Golosov, V.; Chalov, S.; Seto, S.; Yoshimura, K.; Nakamura, S.; Oki, T., 2013. Probability assessment of flood and sediment disasters in Japan using the total runoff-integrating pathways model. International Journal of Disaster Risk Reduction, v. 3, 31-43. https://doi. org/10.1016/J.IJDRR.2012.11.003.

Naghettini, M.; Pinto, E.J.A., 2007. Hidrologia estatística. CPRM, Belo Horizonte (Accessed Mês xx, 20xx) at: http://rigeo.cprm.gov.br/jspui/handle/ doc/454.

Namitha, M.R.; Vinothkumar, V., 2019. Development of empirical models from rainfall-intensity-duration-frequency curves for consecutive Days maximum rainfall using GEV distribution. Journal of Pharmacognosy and Phytochemistry, v. 8, (1), 2705-2709.

Nanvapisheh, A.A., 2021. The comparison between Gumbel and exponentiated Gumbel distributions and their applications in hydrological process. American Journal of Computer Science and Information Technology, v. 9, (3), 80.

Ottero, C.R.; Chargel, L.T.; Hora, M.A.G.M., 2018. Análise de frequência dos dados pluviométricos observados em 2011 a 2013 na região Serrana do Rio de Janeiro. Revista Brasileira de Meteorologia, v. 33, (1), 131-139. http://dx.doi. org/10.1590/0102-7786331007.

Pereira, D.C.; Duarte, L.R.; Sarmento, A.P., 2017. Intensity-duration-frequency curves determination of Ipameri - Goiás. Revista Eletrônica de Engenharia Civil, v. 13, (2), 233-246. http://dx.doi.org/10.5216/reec.V13i2.43330. 
Pérez-Sánchez, J.; Senent-Aparicio, J., 2017. Intensity-duration-frequency curves of short-duration storms in the Segura River Basin, Spain. Agrociência, v. $51,(6), 607-616$.

Ramos, P.L.; Moala, F.A., 2014. A aplicação da distribuição exponencial geométrica estendida para modelagem de dados pluviométricos. Revista Brasileira de Meteorologia, v. 29, (4), 613-620. https://doi.org/10.1590/0102-778620130612.

Rizwan, M.; Guo, S.; Xiong, F.; Yin, J., 2018. Evaluation of various probability distributions for deriving design flood featuring right-tail events in Pakistan. Water, v. 10, (11), 1603. https://doi.org/10.3390/w10111603.

Salinas, J.L.; Castellarin, A.; Kohnová, S.; Kjeldsen, T.R., 2014. Regional parent flood frequency distributions in Europe-Part 2: Climate and scale controls. Hydrology and Earth System Sciences, v. 18, (11), 4391-4401. https://doi. org/10.5194/hess-18-4391-2014.

Santos, G.G.; Griebeler, N.P.; Oliveira, L.F.C., 2010. Chuvas intensas relacionadas à erosão hídrica. Revista Brasileira de Engenharia Agrícola e Ambiental, v. 14, (2), 115-123. https://doi.org/10.1590/S1415-43662010000200001.

Selge, F.; Hagel, H.; Gunkel, G.; Doluschitz, R., 2015. Annual rainfall variability and economical dependency of smallholder agriculture in the Semi-Arid Northeastern region of Brazil. Brazilian Journal of Environmental Sciences, (36), 155-167. https://doi.org/10.5327/Z2176-947820151009.

Silva Neto, V.L.; Viola, M.R.; Silva, D.D.; Mello, C.R.; Pereira, S.B.; Giongo, M., 2017. Daily rainfall disaggregation for Tocantins State, Brazil. Ambiente \& Água, v. 12, (4), 605-617. https://doi.org/10.4136/ambi-agua.2077.

Skees, J.R., 2010. State of Knowledge Report - data requirements for the design of weather index insurance. GlobalAgRisk, Inc., Broadway, 153 pp.
Souza, V.A.S.; Nunes, M.L.A.; Francener, S.F.; Rosa, A.L., 2014. Eventos de precipitações extremas na Amazônia Ocidental: Rondônia - Brasil. Revista Brasileira de Climatologia, v. 14, 295-315. http://dx.doi.org/10.5380/abclima. v14i1.36816.

U.S. Water Resources Council (USWRC). 1981. Guidelines for determining flood flow frequency. Bulletin 17A. Washington, D.C., U.S Geological Survey, 148 pp. https://doi.org/10.3133/tm4B5.

Vivekanandan, N., 2015a. Comparison of L-moments of probability distributions for extreme value analysis of rainfall for estimation of peak flood discharge for ungauged catchments. International Journal of Scientific Research in Science and Technologic, v. 1, (5), 2395-6011.

Vivekanandan, N., 2015b. Quantitative assessment on fitting of Gumbel and Frechet distributions for extreme value analysis of rainfall. International Journal of Scientific Research in Science and Technology, v. 1, (2), 68-73. https://doi.org/10.32628/IJSRST151224.

Vivekanandan, V.; Shukla, S, 2015. Flood frequency analysis using method of moments and L-moments of probability distributions. Cogent Engineering, v. 2, (1), 1018704. https://doi.org/10.1080/23311916.2015.1018704.

Yuan, J.; Emura, K.; Farnham, C.; Alam, M.A., 2018. Frequency analysis of annual maximum hourly precipitation and determination of best fit probability distribution for regions in Japan. Urban Climate, v. 24, 276-286. https://doi. org/10.1016/j.uclim.2017.07.008.

Zhang, W.B.; Xie, Y.; Liu, B.Y., 2002. Rainfall erosivity estimation using daily rainfall amounts. Scientia Geographica Sinica, v. 22, (6), 705-711. https://doi. org/10.13249/j.cnki.sgs.2002.06.705. 